\title{
The Attitude and the Use of Mobile Phones Among Students
}

\author{
Kristiana Dewayani ${ }^{1}$, AristhaJayaKusuma ${ }^{2}$ \\ ${ }^{1}$ Faculty of Psychology, Gunadarma University, Depok West Java, Indonesia, \\ $\triangle$ kdewayani@staff.gunadarma.ac.id \\ ${ }^{2}$ Faculty of Psychology, Gunadarma University, Depok West Java, \\ Indonesia $\bowtie$ aristhajayakusuma@gmail.com
}

\begin{abstract}
The use of mobile phones by students intended for various purposes such as camera, edit the document, download information, social media, and so on. Quantitative research aims to provide an overview of the attitudes and behavior of mobile use among students. The respondent 72 students from a private University in Depok, West Java. Research in methods of survey, the data collected by the scale of the Attitude and Behavior of Mobile Usage . The results of this research show that there is no difference in attitudes towards mobile between men and women, both in terms of ease of use, the benefits of using mobile phones as well as mobile usage frequency. Subsequent findings, the more positive attitude toward mobile phone, the more often students using mobile phone. Interesting things discovered that students who feel the use of mobile useful, does not correlate with the purchase of a data packet, while when the students find it easy to use mobile, followed by the high purchase of data packets. Similarly, in terms of the use of mobile phones as cameras, when the students find it easy to use mobile, then it will be more likely to use mobile phones as cameras.
\end{abstract}

Keywords:attitudes towards mobile usage, mobile self efficacy

This is an open access article distributed under the Creative Commons 4.0 Attribution License, which permits unrestricted use, distribution, and reproduction in any medium, provided the original work is properly cited. $\odot 2018$ by author and Faculty of education, Universitas Negeri Padang.

\section{Introduction}

Indonesia turns out to be in the order to six for most mobile phone usage. Indonesia now has a population as much as 261 million people already use mobile phones as much as 236 million units (Supriadi,2018). The need for information providing devastating effectsgreat for the emergence of information technology that can communicate and get information quickly.

This research was conducted among students, aims to see how students use their mobile. Students are required to always update related information learning in class, be it about the lecture material, or other things related to their social interactions.Mobile phone is one of the communication media which became the primary needs of the students because it has the sophistication in a variety of things as well as effective and efficient functions that can be used anytime and anywhere.

Most of these students are using mobile phone as their communication and information media. By using themobile phone students can be active in social media with ease because mobile phone have 
many features that facilitate its users to connect to the internet more easily anytime and anywhere. The classroom is a place where the destruction process of learning, and wherever possible material of lectures given in appealing to students, so students can focus following the lecture. When the mobile phone becomes an obstacle for students to focus on the lecture, then a lecturer can stimulate students to use mobile as a means of learning tools.

Aoki and Downes (2003) writing down the results of his research that the higher needs of mobile usage will increase the dependence of students with mobile phones. Researchers developed the concept of mobile self efficacy(MSE) based on bandura's concept of self efficacy, and technology acceptance model by Davis (Chuttur, 2009). Self-efficacy is defined as the perception against the ability of the individuals who have influence over their lives. Self-efficacy to determine how people feel, think, motivate yourself and behave. the feeling of being able to produce various effects through the main processes namely cognitive processes, motivation, affective, and the selection process.

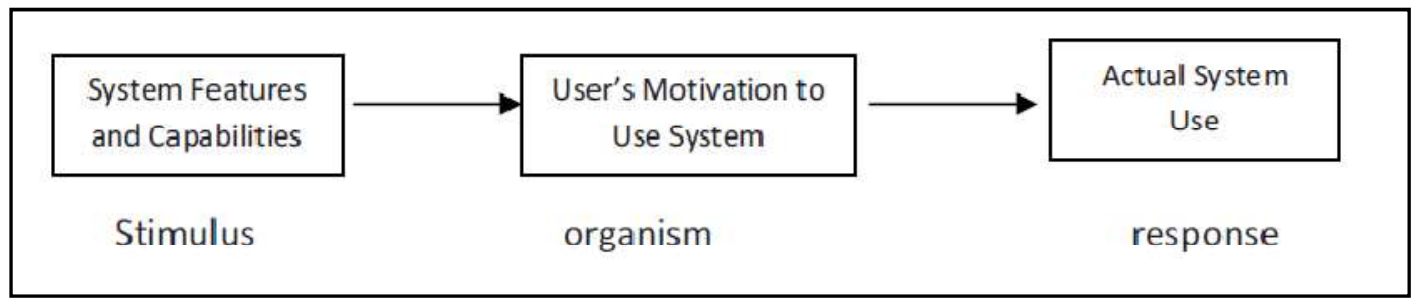

Figure 1: Technology acceptance model

How individuals use mobile is a response that can be explained or predicted by motivation, that is, directly influenced by the external stimulus consisting of different types of hardware or mobile, as well as features on the mobile phone.

Therefore it can be assumed that when students feel to have the ability to use mobile phones, it will have an effect on the use of their mobile phones.This research is a descriptive study, describe the use of mobile phones on the students. This research aims to examine how perceptions of a person's ability to use the phone (mobile self efficacy) willaffect the use of mobile. Researchers propose hypotheses there is a relationship between self-efficacy and use of mobile phones on the students.

\section{Method}

\section{Responden}

Respondent 72 students from a private University in Depok, sampling method used is a non probability sampling. Respondents are students who join the psychology courses,

\section{Instruments}

Measuring instrument used in this research is scale of the Attitude and Behavior of Mobile Usageconsists of the mobile phone self efficacy (MSE) scaleand scale of mobile phone usage (MPU)

MSE scale consists of 3 items have convergent validity AVE $=0.737$, factor loading 0.816-0.887, and construct reliability $\mathrm{CR}=0.894$.

MPU scale consists of 12 items, revealing the use of hand phone as a camera, for sale, for discussion, for the transfer of files, to record the video, connect to friends, to edit photographs, to create, to order transportation, information sources, and to business needs.MPU scale haveconvergenvalidity AVE $=0.590$, factor loading of $0.508-0.914$, and haveconstruct reliability $\mathrm{CR}=$ 0.934 . 


\section{Results and Discussion}

\section{Result}

Before the test the hypothesis, the researchers describe the distribution of respondents based on gender, and based on the response that is given on the use of mobile phones.Data obtained from the 72 respondents, both men and women.

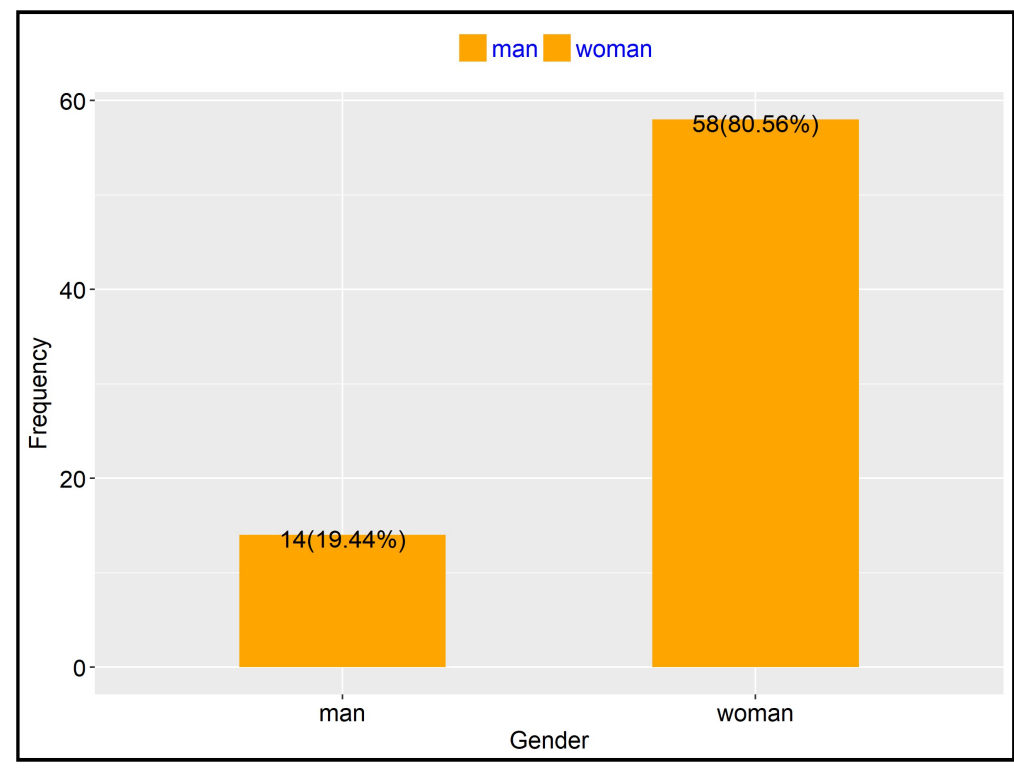

Figure2: respondents based on gender

The majority of respondents in this research is $80.56 \%$ and $19.44 \%$ men.Psychology student majority male-sex. This influenced the distribution of respondents.

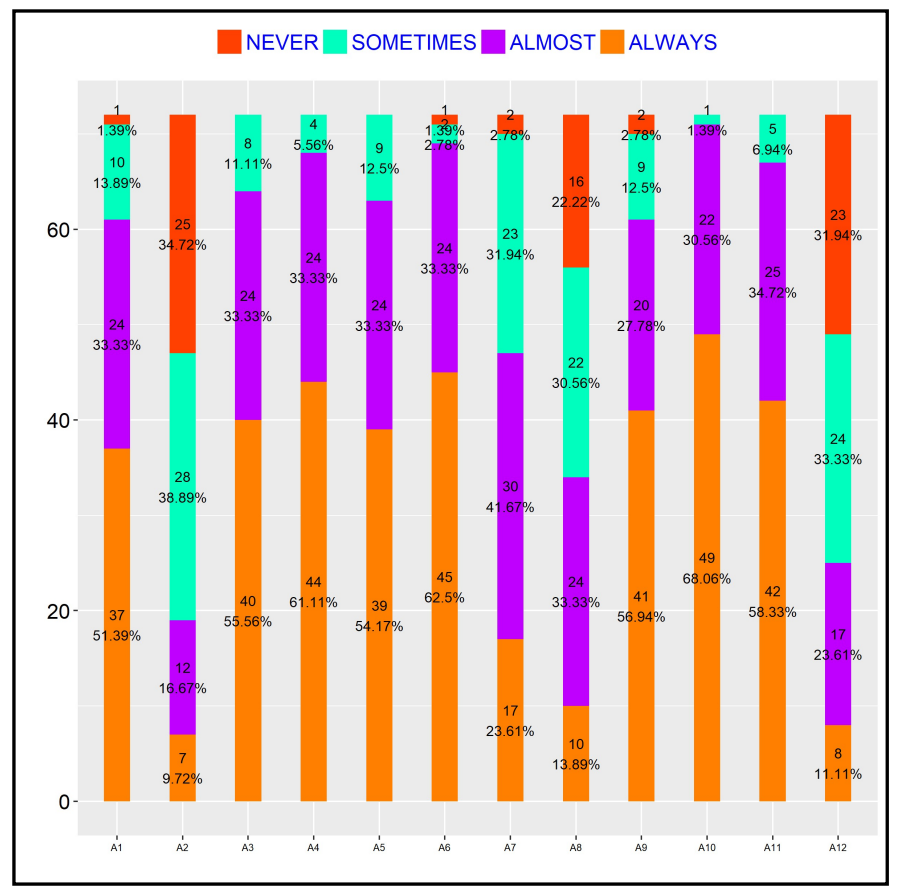

Figure3: Mobile phone usage 
The graph above illustrates how often students using mobile phone as a camera, to sale something, to transfer files, for a discussi, for video recording, to friends, connection to the photo editor, to create something, to transportation orders, for info resources, for information updates, and for the purposes of business. $68 \%$ of students always use the mobile as a source of information, and $61 \%$ of students always use the mobile for the purposes of file transfer. More than $30 \%$ of the students sometimes use mobile to sell something, and for the purposes of the business. In addition, based on the chart above, $41.67 \%$ students almost use mobile as photo editor. And none of the students who never used his mobile phone to the discussion, file transfer, record video, and to access information.

\section{Hypothesis testing}

Hypothesis test is analyzed using the non parametric statistics analysis, and using a significance level of $p$-value $<0.05$ confidence level $95 \%$.

Table 1: test results correlation between the MSE and mobile usage

\begin{tabular}{|c|c|c|c|c|c|c|c|c|c|c|c|c|c|c|}
\hline & & & as camera & $\begin{array}{c}\text { sale } \\
\text { something }\end{array}$ & discussin & $\begin{array}{l}\text { file } \\
\text { transfer }\end{array}$ & $\begin{array}{l}\text { video } \\
\text { recording }\end{array}$ & $\begin{array}{c}\text { friends } \\
\text { connection }\end{array}$ & $\begin{array}{l}\text { photo } \\
\text { editor }\end{array}$ & $\begin{array}{c}\text { create } \\
\text { something }\end{array}$ & $\begin{array}{c}\text { transportat } \\
\text { ion order }\end{array}$ & $\begin{array}{l}\text { info } \\
\text { resources }\end{array}$ & $\begin{array}{l}\text { info } \\
\text { update }\end{array}$ & business \\
\hline \multirow[t]{2}{*}{ MSE } & \multirow{2}{*}{$\begin{array}{l}\frac{\tilde{0}}{0} \\
\frac{\pi}{0} \\
\stackrel{\Xi}{0}\end{array}$} & $\mathrm{r}$ & 0.4145 & 0.1043 & 0.3705 & 0.309 & 0.116 & 0.3186 & 0.3527 & 0.1282 & 0.4047 & 0.4043 & 0.4636 & 0.2134 \\
\hline & & $\mathrm{p}$ & 0.0003 & 0.3831 & 0.0014 & 0.0083 & 0.3319 & 0.0064 & 0.0024 & 0.2832 & 0.0004 & 0.0004 & 0.0001 & 0.0718 \\
\hline
\end{tabular}

* significancyp $<0.05$

The table shows the test results correlation between MSE and mobile usage.MSE correlated positively with the use of mobile phone as a camera $(r=0.415, p=0.0003)$, for discussion $(r=0.371, p=$ $0.0014)$, for file transfer $(r=0.309, p=0.0083)$, for connections with friends $(r=0.319, p=0.0064)$, for transportation order $(r=0.405, p=0.0004)$, to photo editor $(r=0.353, p=0.0024)$, as a source of information $(r=0.404, p=0.0004)$, and to update information $(r=0.464, p=0.0001)$.

The following graph illustrates the correlation between MSE and mobile usage. the program used is the ststistik STATCAL (the Statistics Calculator), developed by Ugi (2018).

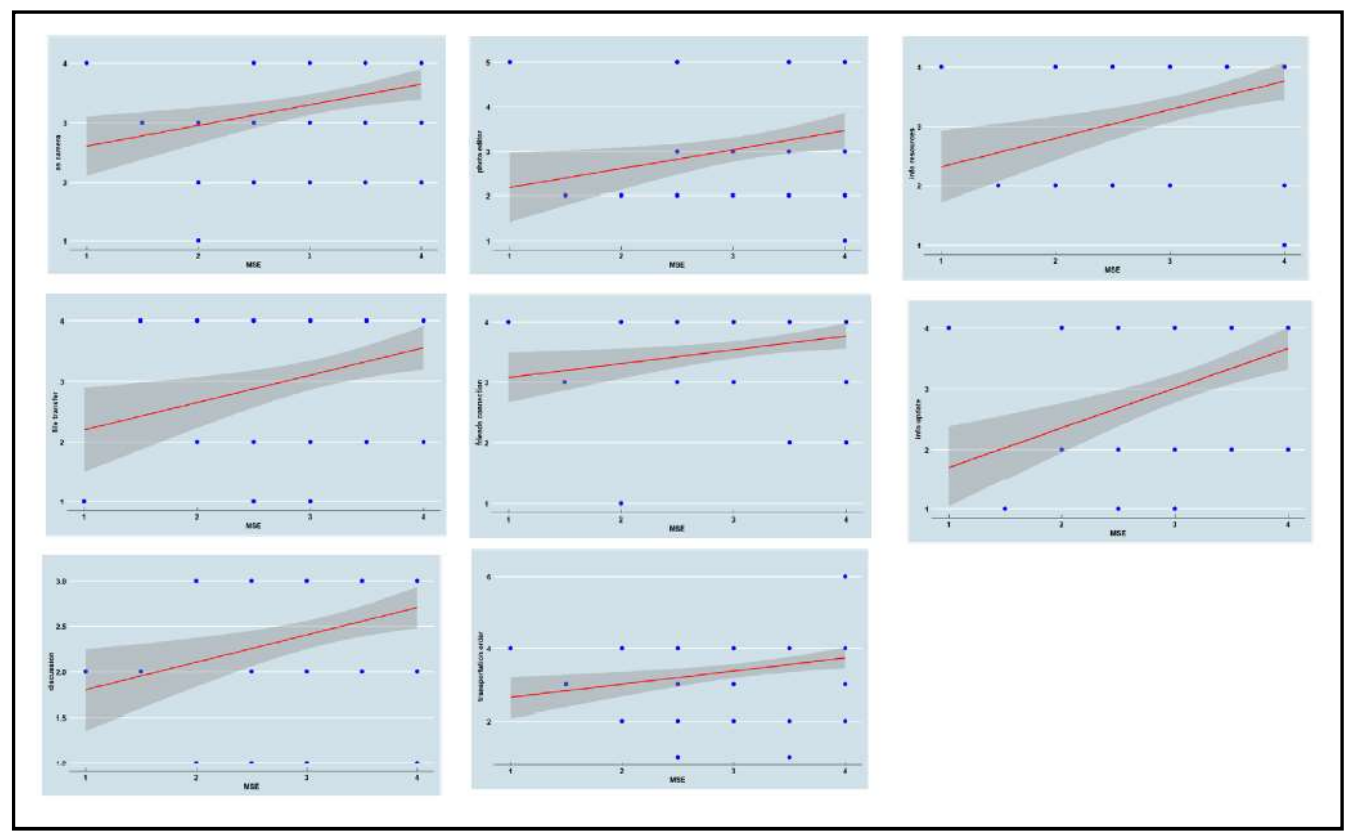

Figure 4: the correlation between MSE and mobile usage 




Figure 5: easy-to-use mobile phone, usefulness and data package purchase

The ease of use of mobile phones by immediately making students will buy the package data. But the usefullnessmobile does not encourage students to buy a data plan. Students prefer to use the campus Wi-Fi or Wi-Fi coffee shop.

Table 2: attitudes towards mobile usage between men and women

ANOVA

\begin{tabular}{|c|c|c|c|c|c|c|}
\hline & & Sum of Squares & $\mathrm{df}$ & Mean Square & $\mathrm{F}$ & Sig. \\
\hline \multirow[t]{3}{*}{ easy to use } & Between Groups & .084 & 1 & .084 & .198 & .657 \\
\hline & Within Groups & 29.569 & 70 & .422 & & \\
\hline & Total & 29.653 & 71 & & & \\
\hline \multirow[t]{3}{*}{ usefullness } & Between Groups & .238 & 1 & .238 & .573 & .452 \\
\hline & Within Groups & 29.081 & 70 & .415 & & \\
\hline & Total & 29.319 & 71 & & & \\
\hline
\end{tabular}

Analysis of the differences between men and women in the use of mobile phones does not find the existence of significant differences. This is because the phone is already a requirement for students..

Attitude is a set of values and belief system around the individual (James \& Woodsmall, 1988). The beliefs of students have the ability to use mobile phones, mobile phone usage purpose variations. They feel that they have the capability of mobile phone usage found it easy to use and useful for them, then using a mobile phone varies as the camera, to connect with friends, to access information, to transportation order.

Belief can be said to be a kind of button on or off from the ability of the individual in doing something. When that individual could sure do, then he would feel able to do it. Instead, individual to do something, unsure about his ability often will make individual true really never could do it. This was confirmed by Bodenhamer and Hall (1999), that the human brain knew what the individual believer, what is and what is not in doubt in believing. It is this that distinguishes how an individual behaves.

\section{Conclusions}

Research of attitude towards the use of mobile phones on a student found a few things, first, the more positive attitude of the students towards the use of mobile phones will be the more often students use their mobile phone for a variety of purposes; Second, there is no difference between men and women in the use of mobile phones; third, when students feel mobile is easy to use, then they 
will be compelled to buy data packages; Fourth, while when students feel the benefits of using mobile, don't make students compelled to buy a data plan.

Suggestions for further research, to examine the use of mobile as a learning media in the classroom, such as task to upload through google's classroom, and so on.

\section{References}

Aoki, K., \& Downes, E. J. (2003). An analysis of young people's use of. Telematics and Informatics(20), 349-364.

Bandura, A. (1994). Self-efficacy. In V. S. Ramachaudran (Ed.), Encyclopedia of human behavior (Vol. 4, pp. 71-81). New York: Academic Press. (Reprinted in H. Friedman[Ed.], Encyclopedia of mental health. San Diego: Academic Press, 1998).

Bodenhamer, B.G., \& Hall, L.M. (1999). The user's manual for the brain; The complete manual for the neurolinguistic programming practitioner certification. Wales: Crown House Publishing Ltd.

Chuttur M.Y. (2009). "Overview of the Technology Acceptance Model: Origins, Developments and Future Directions ," Indiana University, USA . Sprouts: Working Papers on Information Systems, 9(37). http://sprouts.aisnet.org/9-37Sprouts -

Gio, P. U., \&Caraka, R. E. (2018, August 17). PedomanDasarMengolah Data Dengan Program AplikasiStatistikaStatcal. Retrieved from osf.io/vhu84

James, T., \& Woodsmall, W. (1988). Time Line Therapy and The Basis of Personality. Wales: Crown House Publishing Ltd.

https://www.idntimes.com/tech/gadget/eka-supriyadi/daftar-6-negara-pengguna-ponsel-terbanyakdi-dunia-ada-indonesia-c1c2/full/ Published On 31 January 2018 (Aoki \& Downes, 2003) 